This item was submitted to Loughborough's Research Repository by the author.

Items in Figshare are protected by copyright, with all rights reserved, unless otherwise indicated.

\title{
Teaching and learning guide for: regulating the medical profession: from club governance to stakeholder regulation.
}

PLEASE CITE THE PUBLISHED VERSION

http://dx.doi.org/10.1111/j.1751-9020.2010.00345.x

\section{PUBLISHER}

(C) The Author and Blackwell Publishing

\section{VERSION}

AM (Accepted Manuscript)

\section{PUBLISHER STATEMENT}

This work is made available according to the conditions of the Creative Commons Attribution-NonCommercialNoDerivatives 4.0 International (CC BY-NC-ND 4.0) licence. Full details of this licence are available at: https://creativecommons.org/licenses/by-nc-nd/4.0/

\section{LICENCE}

CC BY-NC-ND 4.0

\section{REPOSITORY RECORD}

Chamberlain, J.M.. 2019. "Teaching and Learning Guide For: Regulating the Medical Profession: From Club Governance to Stakeholder Regulation.”. figshare. https://hdl.handle.net/2134/17885. 


\title{
Regulating the Medical Profession: From Club Governance to Stakeholder Regulation
}

\author{
Dr John Martyn Chamberlain
}

Loughborough University

This guide accompanies the following article:

Regulating the Medical Profession: From Club Governance to Stakeholder Regulation], $X X X X$ Compass Vol/Iss (2010) pp. XXX-XXX, [DOI].X

\section{Author's Introduction}

The regulation of the medical profession is an important topic of concern for health and social policy analysts as well as social scientists who possess an academic interest in medical autonomy, institutionalised medical power and contemporary shifts in the governance and performance management of professional forms of expertise. The last three decades have seen substantial changes in how medical work is quality assured to protect the public from medical malpractice and underperforming doctors. Medical practitioners have become increasingly subject to formal peer review mechanisms and third party managerial surveillance and performance appraisal. Bound up with this have been moves toward including lay people as well as other health and social care professionals in the regulation of the medical profession and quality assurance of medical work. This shift has been said to signify a move toward a stakeholder model of medical regulation.

\section{Author Recommends:}

A good place to start understanding the historical background to changes currently occurring in the regulation of medical expertise is Andrew Gray's and Stephen Harrison's Governing Medicine: Theory and Practice (Oxford: Open University Press, 2004). This appraises the current medical regulatory context as well as analyses the impact of contemporary reforms in the quality assurance of health care delivery on medical practice and training. Donald Irvine's The Doctors Tale: Professionalism and the Public Trust, (Radcliffe Medical Press, 2003) provides an insightful 'insider account' of the history of medical regulation in the United Kingdom and the competing interests involved in the contemporary governance of medical expertise. A more critical account of how the medical profession has responded to calls to become more open and accountable can be found in Celia Davies's Regulating the Health Care Workforce: Next Steps for Research (Journal of Health Services Research and 
Policy, 2004 9: 55 - 61) as well as Sally Lloyd-Bostock’s and Bridget Hutter's Reforming Regulation of the Medical Profession: The Risks of Risk Based Approaches (Health, Risk and Society, 2008 1: 69-83)

\section{Online Materials:}

http://www.gmc-uk.org/

This is the website for the General Medical Council, which is the regulatory body responsible for overseeing the governance of the medical profession in the United Kingdom.

http://www.bma.org.uk/

The British Medical Association is the professional medical association and trade union for doctors and medical students.

http://www.bmj.com/

The British Medical Journal is an international peer reviewed medical journal.

\section{Sample Syllabus:}

\section{Week 1 Introduction and overview}

Definitions, Problems \& Issues: Medical Regulation and the Sociological Study of Medical Power and Autonomy

Associated Reading:

Albrecht, G.L, Fitzpatrick, R and Scrimshaw, S.C (2000) The Handbook of Social Science and Medicine Sage Publications

Carr-Saunders, A.M. and Wilson, P.A. (1933) The Professions New York and London: The Clarendon Press

Chamberlain, J.M. (2009) Doctoring Medical Governance: Medical Self-Regulation in Transition New York: Nova Science

Dingwall, R and Lewis, P (1983, editors) The Sociology of the Professions: Lawyers, Doctors and Others London: McMillan

Freidson, E. (1970) The Profession of Medicine New York: Dodds Mead

\section{Week 2 From Ancient beginnings to the birth of the clinic}

Hippocrates, Galen and humoral medicine. Medieval Christianity, the early regulation of the medical profession and the birth of clinic

Associated Reading:

Bynum W.F and Porter, R (1985, editors) William Hunter and the Eighteenth Century Medical World Cambridge University Press

Copeman, W.S.C. (1960) Doctors and Disease in Tudor Times London: Dawson and Sons

Foucault, M. (1989) The Birth of the Clinic: An Archaeology of Medical Perception 
London: Routledge Classics

Lindeman, M. (1999) Medicine and Society in Early Modern Europe Cambridge university press

King, H (2001) Greek and Roman Medicine. London: Bristol Classical Press

Krause, E.A (1996) Death of the Guilds: Professions States and the Advance of

Capitalism Yale: University Press

\section{Week 3 The 1858 Medical Act and the foundation of the medical club}

The 1858 Medical Act and the institutionalization of medical autonomy in the form of the General Medical Council.

Associated Reading:

Allsop, J and Saks, M. (2002, editors) Regulating the Health Professions London: Sage Publications

Chamberlain, J.M. (2009) Doctoring Medical Governance: Medical Self-Regulation in Transition New York: Nova Science

Gladstone, D. (2000, editor) Regulating Doctors London: Institute for the Study of Civil Society

Stacey, M. (1992) Regulating British Medicine London: John Wiley and Sons

\section{Week 4: Challenging medical power I: health service reform}

Medical autonomy, the re-emergence of neo-liberal political ideology and the rise of consumerism and managerialism in the health care system. Introduction of medical and clinical audit and shift from a primary to secondary care led service.

Associated Reading:

Allsop, J and Mulcahy, L. (1996) Regulating Medical Work: Formal and Informal Controls Open University Press

Armstrong, D (2002) Clinical Autonomy, Individual and Collective: The Problem of Changing Doctors Behaviour Social Science and Medicine 55: 1771-1777

Elston, M.A. (2004) Medical Autonomy and Medical Dominance, in, Gabe, J, Bury, $\mathrm{M}$ and Elston, M.A. (2004) Key Concepts in Medical Sociology London: Sage Publications

Flynn, R (2002) Clinical Governance and Governmentality Health Risk and Society 4: 134-167

Harrison, S and Schultz, R.L. (1989) Clinical Autonomy in the UK and the USA:

Contrasts and Convergence in Freddi, G and Bjorkman, J.W (1989, editors)

Controlling Medical Professionals: the Comparative Politics of Health Governance Sage Publications

\section{Week 5: Challenging medical power II: the patient revolt}

Lay perceptions of medicine and medical power. Medical malpractice and the rise of the patient movement. 
Associated Reading:

Barrett, J R, Barrett, P and Kearns, R A (1998) Declining Professional Dominance? Trends in the Proletarianization of Primary Care in New Zealand Social Science and Medicine 46: 193-207

Chamberlain, J.M. (2009) Doctoring Medical Governance: Medical Self-Regulation in Transition New York: Nova Science

Haug, M. R (1973) Deprofessionalization: An Alternative Hypothesis for the Future in Halmos, P (1973, editor) Professionalization and Social Change Sociological Review Monograph 20 University of Keele

Saks, M (1995) Professions and the Public Interest: Medical Power, Altruism and Alternative Medicine London: Routledge

\section{Week 6: Contemporary changes in medical regulation}

The 2008 Health and Social Care Act and reforming the General Medical Council. The emergence of revalidation and the performance appraisal of doctors continued fitness to practice.

Associated Reading:

Chamberlain, J.M. (2009) Doctoring Medical Governance: Medical Self-Regulation in Transition New York: Nova Science

Davies, C. (2004) Regulating the Health Care Workforce: Next Steps for Research Journal of Health Services Research and Policy: 9 (1) 1- 20

Irvine, D. (2003) The Doctors Tale: Professionalism and the Public Trust London:

Radcliffe Medical Press

Moran, M. (1999) Governing the Health Care State; A Comparative Study of the

United Kingdom, the United States and Germany Manchester University Press

\section{Week7: The decline of medical autonomy?}

Reappraising the sociological study of medical regulation: decline or restratification? The emergence of a new power elite within the medical profession

Associated Reading:

Ahmed, W I U and Harrison, S (2000) Medical Autonomy and the UK State: 1975 to 2025 Sociology, 34: 129-46

Chamberlain, J.M. (2009) Doctoring Medical Governance: Medical Self-Regulation in Transition New York: Nova Science

Chamberlain, J.M. (2010) Performance Appraisal for Doctors: A Case of Paperwork Compliance Sociological Research Online 15 (1): 1 - 11. Available online: http://www.socresonline.org.uk/15/1/8.html

Freidson, E. (1994) Professionalism Reborn: Theory, Prophecy and Policy Cambridge Polity Press

Gabe, J, Kelleher, D and Williams, G. (1994) Challenging Medicine London:

Routledge 


\section{Week 8: Future visions: risk, responsibility and the performance appraisal of medical work}

Medicine's new professionalism and next steps in theory and research. The importance of analyzing revalidation and patient involvement in the monitoring of medical work.

\section{Associated Reading:}

Black, D (2002) Consultant Appraisal GMC News Supplement on Appraisal and Revalidation 1- 4. The GMC: London

Chamberlain, J.M. (2009) Doctoring Medical Governance: Medical Self-Regulation in Transition New York: Nova Science

Chamberlain, J.M. (2010) Performance Appraisal for Doctors: A Case of Paperwork

Compliance Sociological Research Online 15 (1): 1 - 11. Available online: http://www.socresonline.org.uk/15/1/8.html

Donaldson, L. (2006) Good Doctors Safer Patients: Proposals to Strengthen The System to Assure and Improve the Performance of Doctors and to Protect the Safety of Patients DOH London

Freidson, E. (2001) Professionalism: The Third Logic Cambridge Polity Press

Gray, A and Harrison, S. (2004, editors) Governing Medicine: Theory and Practice

Open University Press

Kuhlmann, E and Allsop, J. (2008) Professional self-regulation in a changing architecture of governance: Comparing health policy in the UK and German Policy and Politics Health, Risk and Society (36) 2: 173-89

\section{Focus Questions}

1) According to Foucault, how did the birth of the clinic transform the epistemological foundation stones on which the early medical profession stood? What other developments in medical science and technology occurring in the 18th and $19^{\text {th }}$ centuries do you think also contributed to this transformation?

2) 'The 1858 Medical Act secured the interests of the medical profession as much as it served to protect the public from poorly performing doctors'. Critically discuss this statement with reference to a neo-weberian model of medical power.

3) Critically evaluate the impact of consumerism and managerialism on medical autonomy.

4) Summarise the key changes to the General Medical Council introduced by the 2008 Health and Social Care Act and critically discuss if they curtail medical autonomy. 5) Provide a critical account of why studying the impact of revalidation is vitally important to the future study of medical autonomy by social scientists.

\section{Project I dea:}

Construct a portfolio of images which over time tells the story of the rise of modern medicine from Hippocrates and Galen to the birth of the clinic and the rapid advances in medical science made in the nineteenth and twentieth centuries. Provide an accompanying account (1500) words which critically discusses how your narrative 
illustrates the power of 'the medical gaze' and its ability to transform our lives for the better while also opening up new possibilities for the surveillance and control of the population by the state and its agencies. 